\title{
Roving Survey for the Incidence of Leaf Crinkle Disease of Urdbean in Major Urdbean Growing Districts of Tamil Nadu, India
}

\author{
T. Priyanga ${ }^{1 *}$, T. K. S. Latha ${ }^{1}$, T. Ramya Teja ${ }^{1}$, K. Prabakar ${ }^{1}$, \\ V. Balasubramani ${ }^{2}$, M. Raveendran ${ }^{2}$ and G. Karthikeyan ${ }^{1}$ \\ ${ }^{1}$ Department of Plant Pathology, ${ }^{2}$ Department of Plant Biotechnology, Tamil Nadu \\ Agricultural University, Coimbatore, India \\ *Corresponding author
}

\section{A B S T R A C T}

Ke y w o r d s
Urdbean, Leaf
crinkle, Roving
survey, Tamil
Nadu, Percent
disease incidence
(PDI), Insect
diversity

Urdbean (Vigna mungo (L.) Hepper) is an important pulse crop grown in all pulse growing districts of Tamil Nadu. The productivity of urdbean is very low mainly due to yield losses caused by various viral diseases. Urdbean Leaf Crinkle Disease (ULCD) is one of the important viral diseases that affect both the quality and quantity of the seed. An intensive roving survey was conducted during cropping seasons of 2018-2019 in major blackgram growing districts of Tamil Nadu viz., Coimbatore, Villupuram, Cuddalore, Tenkasi, Tirunelveli and Pudukottai to determine disease incidence and insect diversity. The farmers were cultivating blackgram varieties were CO-6, VBN-4, VBN-5, VBN-6, VBN8, KKM-1, MDU-5 and T-9. All the cultivars were found to be susceptible to ULCD ranging from 11.80 to $33.50 \%$. Higher level of disease incidence $(33.50 \%)$ was observed in T-9 variety in Pudukottai district followed by VBN-8 variety $(30.66 \%)$ in Coimbatore district. The lowest level of disease incidence was recorded in VBN-5 (11.80\%) and CO-6 $(12.8 \%)$ in Tenkasi and Coimbatore district respectively. The most prevalence insects visiting the urdbean field were Whitefly, Aphid, Hoppers and Coccinelid beetles.

\section{Introduction}

Urdbean (Vigna Mungo (L) Hepper) is an important food legume used for itsrich source of protein in human diet. The crop is highly prone to attack by fungal, bacterial and viral pathogens which greatly affect its yield drastically. Among the various viral diseases, urdbean leaf crinkle disease (ULCD) is considered as serious one since it affects both the quality and quantity of the seed grain. Urdbean leaf crinkle virus (ULCV) was first reported from Delhi by Nariani (1960) and Williams et al., (1968) and still the etiology is unknown. The infected plants showed crinkling, puckering, curling, malformation of leaves and flowers (Bindra, 1971).

The transmission of ULCD is mainly through infected seed (Narayanasamy and Jaganathan, 1975; Kanimozhi et al., 2009), infected sap (Biswas et al., 2012), insect vectors (Sravika et al., 2018) but not transmitted through soil (Beniwal et al., 1983). The yield losses were 
reported by several authors (Beniwal and Chaubey, 1979; Kadian, 1982; Bashir et al., 1991; Kadian, 1994; Sharma et al., 2007; Kanimozhi et al., 2009). In the present study, leaf crinkle disease incidence was recorded in major urdbean growing districts of Tamil Nadu state.

\section{Materials and Methods}

In Tamil Nadu, Urdbean is cultivated in three seasons viz., summer, Kharif and Rabi besides rice fallow in certain districts. An intensive roving survey was conducted in major urdbean growing districts of Tamil Nadu viz., Coimbatore, Villupuram, Cuddalore, Tirunelveli, Tenkasi and Pudukottai to understand the prevalence of leaf crinkle disease incidence and insects as vectors during cropping seasons of 2018-2019. Two fields in each village were selected and in each field 10 quadrats (each 25sq.m area) were randomly selected and disease incidence was recorded at 45 days after sowing (Bhavani and Manoj Kumar, 2017). The percent disease incidence (PDI) was assessed by recording the number of plants having symptoms and total number of plants examined by using the following formula:

PDI $(\%)=\frac{\text { Number of infected plants }}{\text { Total number of plants }} \times 100$

During the survey information on cultivation under rainfed or irrigation conditions, cropping season, variety and presence of insects were recorded.

\section{Results and Discussion}

Results obtained from roving survey conducted on leaf crinkle disease incidence in major urdbean growing districts of Tamil Nadu during cropping seasons of 2018-2019 are presented in Table 1. The ULCD infected plants showed severe leaf crinkling, malformation of auxiliary buds and stunted growth of the stem (Fig. 1). The farmers were cultivating blackgram varieties viz., CO-6, VBN-4, VBN-5, VBN-6, VBN-8, KKM-1, MDU-5 and T-9 (Table 1). All the cultivars were found to be susceptible to ULCD ranging from 11.80 to $33.50 \%$.

Table.1 Incidence of urdbean leaf crinkle disease (ULCD) during cropping season of 2018-2019

\begin{tabular}{|c|c|c|c|c|c|c|c|}
\hline $\begin{array}{l}\text { S. } \\
\text { No }\end{array}$ & $\begin{array}{c}\text { District } \\
\text { (season/ } \\
\text { year) }\end{array}$ & Villages & $\begin{array}{c}\text { GPS } \\
\text { coordinate }\end{array}$ & $\begin{array}{c}* \text { Type } \\
\text { of } \\
\text { farming }\end{array}$ & Cultivar & $\begin{array}{c}\% \\
\text { Disease } \\
\text { Incidence }\end{array}$ & $\begin{array}{l}* * \text { Insect } \\
\text { diversity }\end{array}$ \\
\hline \multirow[t]{5}{*}{1.} & \multirow{5}{*}{$\begin{array}{l}\text { Villupuram } \\
\text { (Rabi/ } \\
\text { 2018-19) }\end{array}$} & Tindivanam & $\begin{array}{l}\mathrm{N} 12^{\circ} 12.547 \\
\mathrm{E} 79^{\circ} 40.143\end{array}$ & IR & VBN-6 & 13.3 & $\mathrm{~W}$ and $\mathrm{B}$ \\
\hline & & Iraiyanur & $\begin{array}{l}\mathrm{N} 12^{\circ} 21.317 \\
\mathrm{E}^{\circ} 9^{\circ} 67.021\end{array}$ & IR & VBN-8 & 17.5 & A \\
\hline & & Iraiyanur & $\begin{array}{l}\text { N12 }{ }^{\circ} 19.574 \\
\text { E79 }^{\circ} 66.546\end{array}$ & IR & VBN-4 & 31.4 & B \\
\hline & & Pangalathur & $\begin{array}{l}\mathrm{N} 12^{\circ} 17.649 \\
\mathrm{E} 79^{\circ} 45.416\end{array}$ & IR & VBN-5 & 21.9 & A \\
\hline & & Pangalathur & $\begin{array}{l}\mathrm{N} 12^{\circ} 17.326 \\
\mathrm{E} 79^{\circ} 45.330\end{array}$ & IR & VBN-5 & 19.8 & W \\
\hline
\end{tabular}




\begin{tabular}{|c|c|c|c|c|c|c|c|}
\hline & & Pangalathur & $\begin{array}{l}\mathrm{N} 12^{\circ} 16.915 \\
\mathrm{E} 79^{\circ} 46.177\end{array}$ & $\mathrm{RF}$ & VBN-5 & 29.2 & $\mathrm{~W}$ \\
\hline & & Siruvadi & $\begin{array}{l}\mathrm{N} 12^{\circ} 12.637 \\
\mathrm{E}^{\circ} 9^{\circ} 51.052\end{array}$ & IR & VBN-5 & 18.6 & $\mathrm{~W}, \mathrm{~A}$ \\
\hline & & Siruvadi & $\begin{array}{l}\mathrm{N} 12^{\circ} 14.987 \\
\mathrm{E} 79^{\circ} 51.082\end{array}$ & $\mathrm{RF}$ & VBN-6 & 15.8 & W \\
\hline & & Agoor & $\begin{array}{l}\mathrm{N} 12^{\circ} 12.689 \\
\mathrm{E} 79^{\circ} 51.053\end{array}$ & $\mathrm{RF}$ & VBN-5 & 15.7 & W \\
\hline 2. & $\begin{array}{l}\text { Cuddalore(R } \\
\text { abi/ } \\
\text { 2018-19) }\end{array}$ & Palur & $\begin{array}{l}\mathrm{N} 11^{\circ} 44.772 \\
\mathrm{E} 79^{\circ} 38.195\end{array}$ & IR & MDU-5 & 13.3 & A \\
\hline \multirow[t]{4}{*}{3.} & \multirow{4}{*}{$\begin{array}{l}\text { Pudukottai(R } \\
\text { abi/ } \\
\text { 2018-19) }\end{array}$} & Vamban & $\begin{array}{l}\mathrm{N} 10^{\circ} 36.755 \\
\mathrm{E} 78^{\circ} 91.275\end{array}$ & IR & VBN-6 & 15.8 & $\mathrm{~W}, \mathrm{~A}$ \\
\hline & & Vamban & $\begin{array}{l}\text { N10 } 36.842 \\
\text { E78 }\end{array}$ & IR & VBN-8 & 29.8 & $\mathrm{~W}, \mathrm{~A}$ \\
\hline & & Vadakadu & $\begin{array}{l}\mathrm{N} 10^{\circ} 34.648 \\
\mathrm{E} 79^{\circ} 05.744\end{array}$ & IR & T-9 & 33.5 & W \\
\hline & & Vadakadu & $\begin{array}{l}\mathrm{N} 10^{\circ} 34.648 ; \\
\mathrm{E} 79^{\circ} 05.744\end{array}$ & IR & VBN-6 & 20.7 & W \\
\hline 4. & $\begin{array}{l}\text { Tirunelveli } \\
\text { (Summer/ } \\
\text { 2019) }\end{array}$ & Killikulam & $\begin{array}{l}\text { N08 } 70.338 \\
\text { E77 }^{\circ} 51.347\end{array}$ & $\mathrm{RFw}$ & KKM-1 & 13.4 & W \\
\hline \multirow[t]{2}{*}{5.} & \multirow{2}{*}{$\begin{array}{l}\text { Tenkasi } \\
\text { (Summer/ } \\
\text { 2019) }\end{array}$} & Panpozhi & $\begin{array}{l}{\mathrm{N} 09^{\circ} 01.209}^{\mathrm{E} 77^{\circ} 15.161}\end{array}$ & $\mathrm{RFw}$ & VBN-8 & 26.4 & W, LH \\
\hline & & Pavoor & $\begin{array}{l}\text { N08 } 55.633 \\
\mathrm{E}^{\circ} 7^{\circ} 23.434\end{array}$ & IR & VBN-5 & 11.8 & W \\
\hline \multirow[t]{4}{*}{6.} & \multirow{2}{*}{$\begin{array}{l}\text { Coimbatore } \\
\text { (Rabi/ 2018- } \\
\text { 19) }\end{array}$} & $\begin{array}{l}\text { Pullagoundanputh } \\
\text { ur }\end{array}$ & $\begin{array}{l}\mathrm{N} 10^{\circ} 97.916 \\
\mathrm{E} 76^{\circ} 83.606\end{array}$ & IR & $\mathrm{CO}-6$ & 14.6 & $\mathrm{~W}, \mathrm{~A}$ \\
\hline & & Devarayapuram & $\begin{array}{l}\text { N10 } 99.764 ; \\
\mathrm{E} 76^{\circ} 81.587\end{array}$ & IR & $\mathrm{CO}-6$ & 12.8 & $\mathrm{~A}, \mathrm{~B}$ \\
\hline & $\begin{array}{l}\text { Summer/ } \\
2019\end{array}$ & Thondamuthur & $\begin{array}{l}\mathrm{N} 10^{\circ} 98.992 \\
\mathrm{E} 76^{\circ} 84.088\end{array}$ & $\mathrm{RF}$ & VBN-6 & 13.5 & W \\
\hline & Kharif/ 2019 & TNAU & $\begin{array}{l}\mathrm{N} 11^{\circ} 01.347 \\
\mathrm{E} 76^{\circ} 93.724\end{array}$ & IR & VBN-8 & 30.66 & $\mathrm{~A}, \mathrm{~W}, \mathrm{LH}$ \\
\hline
\end{tabular}

* RF: Rainfed; IR: Irrigated; RFw: Rice fallow

** A: Aphid; B: Coccinelid beetle; LH- Leaf hopper; W: Whitefly 
Fig.1 The leaf crinkle disease symptoms observed in all the districts were similar viz., Crinkling of lamina, stunted growth and floral malformation (A-K. Crinkling of leaves; L. Malformation of auxiliary buds). A. VBN-8 (Iraiyanur); B. VBN-4 (Iraiyanur); C. VBN-5 (Pangalathur); D. VBN-6 (Vadakadu); E. VBN-5 (Siruvadi); F. MDU-5 (Palur); G. VBN-8 (Panpozhi); H. T-9 (Vadakadu); I. VBN-5 (Pavoor); J. KKM-1 (Killikulam); K. CO-5 (TNAU); L. VBN-8 (TNAU)

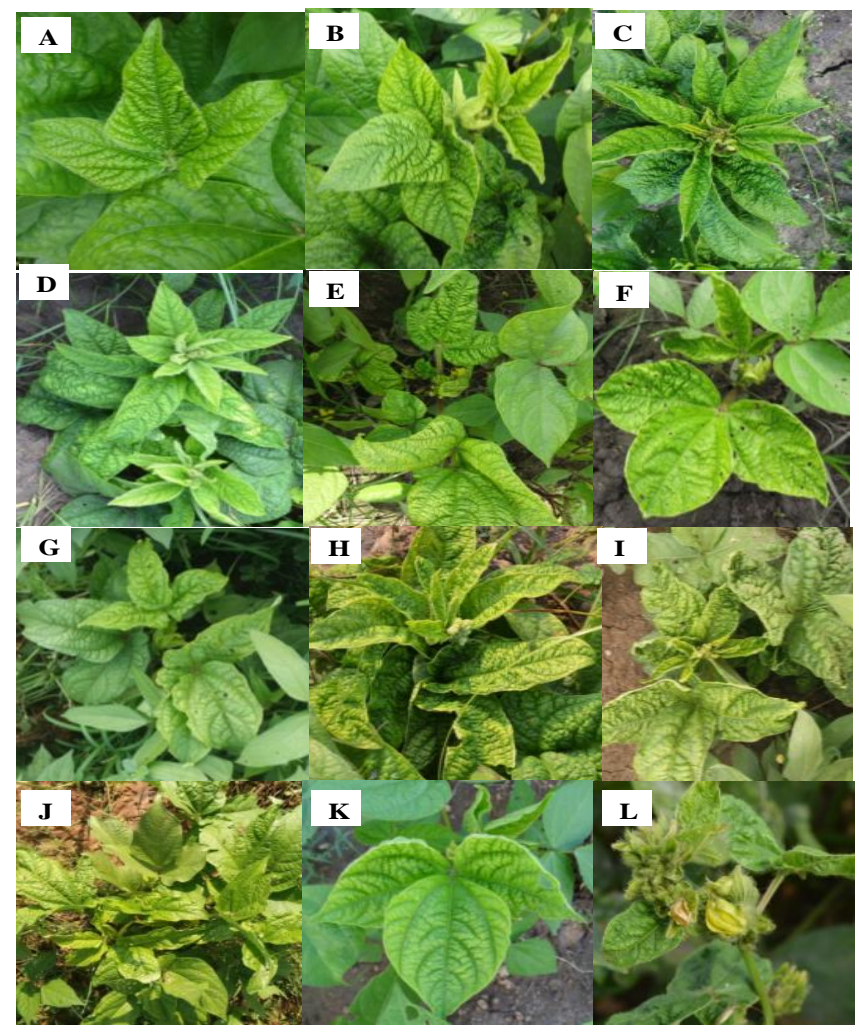

Among the all varieties, higher level of disease incidence $(33.50 \%)$ was observed in T-9 variety in Pudukottai district followed by VBN-8 variety $(30.66 \%)$ in Coimbatore district. The lowest level of disease incidence was recorded in VBN-5 (11.80\%) and CO-6 (12.8\%) in Tenkasi and Coimbatore district respectively (Table 1).

According to Vijaykumar (1993), the incidence of ULCV disease ranging from 1.15 to $4.52 \%$ in Guntur district of Andhra Pradesh (AP) and the incidence was high during Rabi (1.25-7.52\%) compared to Kharif-1993 (1.15-4.52\%) and rice fallows (1.10-2.52\%). In Uttar Pradesh, the incidence of ULCD varies from 28 to $85 \%$ under natural conditions (Srivastava, 2005). The disease incidence of ULCD was 14.4-20.5\% and yield losses upto $91 \%$ during successive years from 2006 to 2009 (Biswas et al., 2015). Disease incidence was varying in all surveyed districts of the state (Table 1). This may be due to variation in environmental factors, health of seed material, population and movement of vectors. Similarly, Haller and Byadgi (2019) also reported about the spread of leaf crinkle disease in greengram under field conditions. Since the incidence of ULCD under natural condition is increasingly alarming. Studies on the etiology and transmission have to be strengthened in order to develop as management strategy of this dreadful disease.

\section{Acknowledgments}

The authors are highly thankful to Department of Biotechnology, New Delhi for providing financial assistance. 


\section{References}

Bashir, M., Mughal, S. M., Malik, B. A. (1991).Assessment of yield losses due to leaf crinkle virus in urdbean (Vigna mungo (L) Hepper). Pak. J. Bot. 23: 140142.

Beniwal, S.P.S., Chaubey, S.N. (1979). Urdbean leaf crinkle diseases: effect on yield contributing factors, total yield and seed characters of urdbean (Vigna mungo). Seed Res. 7:125- 181.

Beniwal, S.P.S., Chaubey, S.N., Matheswaran, C. (1983b). Some factors affecting transmission of Urdbean leaf crinkle virus through seeds of urdbean (Vigna mungo (L.) Hepper). SeedResearch.11: 95-99.

Bhavani, G., Manoj Kumar, V. (2017). Evaluation of urdbean germplasm for resistance to leaf crinkle disease.Internat. J. Plant Sci: 13 (1): 118-123.

Bindra O.S. (1971).Studies on arthropods in relation to plant disease in Punjab.International symposium Plant pathology, IARI, New Delhi, 20-22.

Biswas, K.K., Tarafdar, A., Biswas, K. (2012). Viral diseases and its mixed infection in mungbean and urdbean. Modern trends in microbial biodiversity of natural ecosystem. New Delhi: Biotech Books: 301-317.

Haller, H., Byadgi, A. S. (2019). Incidence of leaf crinkle disease on greengram in northern Karnataka. Plant Archives. 19(2): 2411-2418.

Kadian, O.P. (1982). Yield loss in mungbean and urdbean due to leaf crinkle disease. Indian Phytopath. 35: 642 -644.
Kadian, O. P. (1994). Mechanical and seed transmission of urdbean leaf crinkle virus (ULCV) in Haryana. Crop Res. 8:565569 .

Kanimozhi, S., Ganapathy, T., Rajinimala, N. (2009). Seed transmission of ULCV in Mungbean and Urdbean plants infected with both MYMV and ULCV. Arch. Phytopath. Plant Protec. 42: 401-408.

Narayanasamay, P., Jaganathan, T. (1975).Seed transmission of urdbean leaf crinkle virus. Phytopath Z.82:107 - 110 .

Nariani, T.K. (1960). Yellow mosaic of mung (Phaseolus aureus L.). Indian. Phytopath. 13:24 -29.

Sharma, R. B., Prasad, S. M., Kudada, N. (2007). Leaf crinkle virus disease in urdbean (Vignamungo Linn.). J. Res. BirsaAgrl. Univ. 19: 73-79.

Sravika, A., Kennedy, J. S., Rajabaskar, D., Rajeswari, E. (2018). Transmission of leaf crinkle virus in blackgram (Vigna mungo L.). Int. J. Curr. Microbiol.App. Sci. 7(11): 2514-2523.

Srivastav, S. (2005). Studies on virus diseases of urdbean (Phaseolus mungo L.), Ph.D Thesis, V. B. S. PurvanchalUniversity, Jaunpur, Uttar Pradesh, (India).

Vijaykumar, S. (1993). Studies on Blackgram leaf crinkle virus. M. Sc. (Ag.) Thesis. Acharya N G Ranga Agricultural University, Hyderabad, India.

Williams, P.J., Grewal, J.S., Amin, K.S. (1968). Serious and new diseases of pulse crops in India in 1966. Plant. Dis Reptr. 52: 300-304.

\section{How to cite this article:}

Priyanga, T., T. K. S. Latha, T. Ramya Teja, K. Prabakar, V. Balasubramani, M. Raveendran and Karthikeyan, G. 2020. Roving Survey for the Incidence of Leaf Crinkle Disease of Urdbean in Major Urdbean Growing Districts of Tamil Nadu, India. Int.J.Curr.Microbiol.App.Sci. 9(10): 17801784. doi: https://doi.org/10.20546/ijcmas.2020.910.216 